\title{
The Importance of Preventing a Metabolic Syndrome Pandemic After the COVID-19 Outbreak
}

\section{COVID-19 Pandemisi Sonrasında Metabolik Sendrom Pandemisini Önlemenin Önemi}

\author{
Ömer Özkan ${ }^{1}$, Levend Karaçoban¹, Gürhan Dönmez ${ }^{1}$, Ali Haydar Demirel ${ }^{1,2}$ \\ ${ }^{1}$ Department of Sports Medicine, Faculty of Medicine, Hacettepe University, Ankara, Turkey \\ ${ }^{2}$ Faculty of Sport Sciences, Hacettepe University, Ankara, Turkey
}

\author{
Ö. Özkan \\ 0000-0002-0815-6494 \\ L. Karaçoban (iD) \\ 0000-0003-1198-196X \\ G. Dönmez (iD \\ 0000-0001-6379-669X \\ A.H. Demirel (iD \\ 0000-0003-3334-4793 \\ Geliş Tarihi/Date Received: \\ 02.05.2020 \\ Kabul Tarihi/Date Accepted: \\ 05.05.2020 \\ Yayin Tarihi/Published Online: \\ 22.06.2020

\section{Yazışma Adresi /} \\ Corresponding Author: \\ Ömer Özkan \\ Hacettepe Üniversitesi, Spor \\ Hekimliği Anabilim Dalı, \\ Ankara, Turkey \\ E-mail: \\ dr.omerozkan@hotmail.com
}

(C2020 Türkiye Spor Hekimleri Derneği. Tüm hakları saklıdır.
Metabolic Syndrome (MetS) is a constellation of abdominal obesity, insulin resistance, hypertension, and hyperlipidemia and also has gained worldwide attention in the past few years $(1,2)$. Physical inactivity is one of the predominant underlying risk factors for this syndrome $(1,2)$. MetS is considered a worldwide epidemic, and as such, could become what we consider a pandemic $(2,3)$. Metabolic syndrome now affects more than a billion people throughout the world based on current estimates (2).

The December 2019 coronavirus disease (COVID-19) outbreak has spread all around the world. As a reaction to this, many countries have imposed quarantine, curfew, or self-isolation of the public as preventive measures. Unfortunately, isolation predicts declines in physical activity levels and social distancing produces a significant increase in unhealthy eating $(4,5)$. Even prior to the COVID-19 outbreak, people with metabolic syndrome spent a higher percentage of time as sedentary than those without this syndrome $(67,3 \%$ vs. $62,2 \%$, respectively) (6). Risks of inactivity are underscored by data that shows that sitting $>42$ hours per week had a $4 \%-12 \%$ attributable risk of metabolic syndrome, central obesity, and high serum triglyceride levels in both genders, as well as abnormal serum glucose levels and diastolic blood pressure in women (7). Voluntarily reducing daily step counts from a mean of $10501 \pm 808$ steps/day to $1344 \pm 33$ steps/day for only 2 weeks results in a decrease in $\mathrm{VO}_{2 \max }$, lean body mass and also a decline in peripheral insulin sensitivity (8).

A large number of studies have reported the benefits of regular physical activity for a healthy life (9). Some studies show that women and socially isolated populations are vulnerable to the development of physical inactivity (10). Social isolation and being disconnected from other people are consistently and strongly associated with a variety of poor health outcomes and behaviors in all age groups (11). Consequently, a sedentary lifestyle, less physical activity and bad eating habits are highly correlated to an increased risk of metabolic syndrome $(1,12)$. 
There is clear scientific evidence proving the benefit of regular physical activity (13-15). Almost any type of exercise is beneficial, with as little as one hour per week providing substantial benefits on the risk of coronary heart diseases (CHD) and mortality (15). Studies show that a significant reduction in the risk of cardiovascular disease and mortality with as little as one hour of moderate or high exertion per week (14). Participating in resistance exercise, even less than one hour per week, was associated with a lower risk of developing MetS (13).

Restrictions for the COVID-19 outbreak including home-isolation are expected to result in a decrease in physical activity and an increase in bad eating habits and sedentary lifestyles of people worldwide. A comprehensive program of home exercise, including aerobic, resistance, flexibility, and neuromotor exercises of sufficient volume and quality, is recommended to minimize the negative aspects of this recently enforced lifestyle $(1,16)$. However, most individuals face challenges implementing a comprehensive home exercise program because of both the negative psychological effects of the pandemic and a less than ideal setting for physical activity in most homes (17). Predictions about how long the existing restrictions will last vary but strong evidence shows that switching lifestyle from active to sedentary for only 2 months would lead to elevated measures MetS development (18). Exercise, a healthy diet, and lifestyle changes are the first-line treatment and prevention options for MetS. These are both efficient and broad-spectrum medications. Studies showed their positive effects on obesity, hyperlipidemia, high blood pressure, insulin resistance, serum glucose levels, and mental health (2). Due to homeisolation, physicians are not able to use these essential medications against MetS. Before the COVID-19 outbreak, many MetS patients changed their lifestyles to maintain their physical and mental health, after the homeisolation period; they may not be able to continue this kind of a lifestyle. Habits and lifestyle changes take time to adapt, and people who get used to staying at home sedentary and having bad eating habits would become potential victims of the growing MetS pandemic.

Epidemiologic data shows a dramatic increase in the prevalence of obesity in most countries, especially in the young population (2). At the same time, the incidence of metabolic syndrome parallels the incidence of obesity, type 2 diabetes, hyperlipidemia, and other comorbidities. More than a quarter of the global population does not have enough physical activity (19). In the period following the COVID-19 outbreak, with a further reduction in activity levels, we can foresee the potential for a dramatic increase in metabolic syndrome and related diseases.

The healthcare cost of a MetS pandemic is in trillions. (i.e., average annual total costs of living between people with metabolic syndrome versus no metabolic syndrome differ by a magnitude of 1,6 overall). Moreover, total costs were reported to further increase by an average of $24 \%$ per additional risk factor (20). These health cost considerations alone suggest that physical activities during the pandemic are crucial. Obviously, to be successful, steps taken should be more than recommending basic exercises. Coordinated efforts should be made to reduce the underlying causes of the syndrome - including motivation to exercise, poor nutritional choices and psychological barriers to losing weight (3). To prevent this possible "metabolic syndrome pandemic secondary to COVID-19 outbreak", there is an urgent need for newly adopted comprehensive health policies and innovative programs to promote exercise, weight loss and better nutrition for 'during and after' pandemic periods. Failing to do this may leave us unprepared for yet another pandemic.

Available at: http://journalofsportsmedicine.org and http://dx.doi.org/10.5152/tjsm.2020.197 
Cite this article as: Ozkan O, Karacoban L, Donmez G, Demirel $\mathrm{AH}$. The importance of preventing the metabolic syndrome pandemic after the COVID-19 outbreak. Turk $J$ Sports Med. 2020;55(3):256-8.

\section{Acknowledgment}

The authors would like to thank Prof. Karl B. Fields and Prof. Bülent Ülkar for constructive criticism of the manuscript.

\section{Conflict of Interest}

The authors declared no conflicts of interest with respect to the authorship and/or publication of this article.

\section{REFERENCES}

1. Grundy SM, Cleeman JI, Daniels SR, Donato KA, Eckel RH, Franklin BA, et al. Diagnosis and Management of the Metabolic Syndrome. Circulation. 2005 Oct 25;112(17):2735-52.

2. Saklayen MG. The Global Epidemic of the Metabolic Syndrome. Curr Hypertens Rep. 2018 Feb;20(2):12.

3. Grundy SM. Metabolic Syndrome Pandemic. Arterioscler Thromb Vasc Biol. 2008 Apr;28(4):629-36.

4. Hawkley LC, Thisted RA, Cacioppo JT. Loneliness Predicts Reduced Physical Activity: Cross-Sectional \& Longitudinal Analyses. Heal Psychol. 2009 May;28(3):354-63.

5. Baumeister RF, Nathan Dewall C, Ciarocco NJ, Twenge JM. Social exclusion impairs self-regulation. J Pers Soc Psychol. 2005 Apr;88(4):589-604.

6. Bankoski A, Harris TB, McClain JJ, Brychta RJ, Caserotti $P$, Chen KY, et al. Sedentary activity associated with metabolic syndrome independent of physical activity. Diabetes Care. 2011 Feb;34(2):497-503.

7. Xiao J, Shen C, Chu MJ, Gao YX, Xu GF, Huang JP, et al. Physical Activity and Sedentary Behavior Associated with Components of Metabolic Syndrome among People in Rural China. PLoS ONE. 2016 Jan 20;11(1):e0147062.

8. Krogh-Madsen R, Thyfault JP, Broholm C, Mortensen $\mathrm{OH}$, Olsen RH, Mounier R, et al. A 2-wk reduction of ambulatory activity attenuates peripheral insulin sensitivity. J Appl Physiol. 2010 May;108(5):1034-40.

9. Jan Mohamed HJB, Mitra AK, Zainuddin LRM, Leng SK, Wan Muda WM. Women Are at a Higher Risk of
Metabolic Syndrome in Rural Malaysia. Women Heal. 2013 May;53(4):335-48.

10. Willey JZ, Paik MC, Sacco R, Elkind MSV, Boden-Albala B. Social determinants of physical inactivity in the Northern Manhattan Study (NOMAS). J Community Health. 2010 Dec;35(6):602-8.

11. Hämmig 0 . Health risks associated with social isolation in general and in young, middle and old age. PLoS One. 2019;14(7).

12. Shin A, Lim SY, Sung J, Shin HR, Kim J. Dietary Intake, Eating Habits, and Metabolic Syndrome in Korean Men. J Am Diet Assoc. 2009 Apr;109(4):633-40.

13. Bakker EA, Lee D chul, Sui X, Artero EG, Ruiz JR, Eijsvogels TMH, et al. Association of Resistance Exercise, Independent of and Combined With Aerobic Exercise, With the Incidence of Metabolic Syndrome. Mayo Clin Proc. 2017 Aug 1;92(8):1214-22.

14. Lee DC, Pate RR, Lavie CJ, Sui X, Church TS, Blair SN. Leisure-time running reduces all-cause and cardiovascular mortality risk. J Am Coll Cardiol. 2014 Aug 5;64(5):472-81.

15. Tanasescu M, Leitzmann MF, Rimm EB, Willett WC, Stampfer MJ, Hu FB. Exercise type and intensity in relation to coronary heart disease in men. $\mathrm{J} \mathrm{Am} \mathrm{Med}$ Assoc. 2002 Oct 23;288(16):1994-2000.

16. Garber CE, Blissmer B, Deschenes MR, Franklin BA, Lamonte MJ, Lee IM, et al. Quantity and quality of exercise for developing and maintaining cardiorespiratory, musculoskeletal, and neuromotor fitness in apparently healthy adults: Guidance for prescribing exercise. Med Sci Sports Exerc. 2011 Jul;43(7):1334-59.

17. Brooks SK, Webster RK, Smith LE, Woodland L, Wessely $\mathrm{S}$, Greenberg $\mathrm{N}$, et al. The psychological impact of quarantine and how to reduce it: rapid review of the evidence. The Lancet. 2020 Mar;395(10227):912-20.

18. Chen SY, Chen SM, Chang WH, Lai CH, Chen MC, Chou $\mathrm{CH}$, et al. Effect of 2-month detraining on body composition and insulin sensitivity in young female dancers. Int J Obes. 2006 Jan;30(1):40-4.

19. Guthold R, Stevens GA, Riley LM, Bull FC. Worldwide trends in insufficient physical activity from 2001 to 2016: a pooled analysis of 358 population-based surveys with 1.9 million participants. The Lancet Global Health. 2018 Oct;6(10):e1077-e1086.

20. Boudreau DM, Malone DC, Raebel MA, Fishman PA, Nichols GA, Feldstein AC, et al. Health care utilization and costs by metabolic syndrome risk factors. Metab Syndr Relat Disord. 2009 Aug 1;7(4):305-13. 